\title{
PENGEMBANGAN PERANGKAT PEMBELAJARAN KIMIA MODEL ARGUMENT DRIVEN INQUIRY UNTUK MENINGKATKAN KETERAMPILAN ARGUMENTASI DAN HASIL BELAJAR SISWA
}

\author{
Suryanto Hadiwidodo ${ }^{1)}$, Tukiran ${ }^{2)}$, Titik Taufikurahmah ${ }^{3)}$ \\ ${ }^{1)}$ Program Studi Pendidikan Sains, Program Pascasarjana Universitas Negeri Surabaya, \\ ${ }^{2)}$ Dosen Program Studi Pendidikan Sains, Program Pascasarjana Universitas Negeri Surabaya \\ ${ }^{3}$ Dosen Program Studi Pendidikan Sains, Program Pascasarjana Universitas Negeri Surabaya \\ email: surpakar4@gmail.com
}

\begin{abstract}
Abstrak: Penelitian ini bertujuan menghasilkan perangkat pembelajaran kimia pada materi pokok reaksi redoks setelah implementasi pembelajaran dengan model pembelajaran Argument Driven Inquiry (ADI). Subjek penelitian adalah siswa kelas XASMK Farmasi Sekesal Surabaya Tahun Pelajaran 2016/2017 sebanyak 30 orang. Teknik pengumpulan data yang digunakan dalam penelitian ini adalah validasi, observasi, tes, dan angket. Hasil penelitian menunjukkan bahwa: (1) validitas RPP, Buku Ajar Siswa, Lembar Kerja Siswa, dan Tes Hasil Belajar berkategori valid; (2) tingkat keterbacaan Buku Ajar Siswa dan Lembar Kerja Siswa berkategori baik; (3) keterlaksanaan pembelajaran berkategori baik; (4) aktivitas siswa dalam pembelajaran berpusat pada siswa; (5) pembelajaran mendapat respons positif dari siswa; (6) mayoritas siswa mencapai peningkatan keterampilan argumentasi (7) mayoritas siswa mencapai peningkatan hasil belajar aspek pengetahuan, sikap, dan keterampilan. Berdasarkan hasil penelitian tersebut dapat disimpulkan bahwa implementasi pembelajaran dengan model pembelajaran Argument Driven Inquiry (ADI) efektif untuk meningkatkan keterampilan argumentasi dan hasil belajar siswa pada materi pokok reaksi redoks.
\end{abstract}

Kata Kunci: perangkat pembelajaran, model pembelajaran Argument Driven Inquiry, hasil belajar.

\section{PENDAHULUAN}

Amanat UU Nomor 20 Tahun 2003 tentang Sistem Pendidikan Nasional,Pemerintah mengemban tugas dalam penyelenggaraan pendidikan nasional harus melaksanakan penyempurnaan secara terus menerus sesuai dengan perkembangan ilmu pengetahuan dan teknologi. Hal ini tampak pada Kurikulum 2013 yang lebih menekankan pada pendidikan model karakter dan kompetensi, sehingga diharapkan menciptakan hasil didik yang mempunyai penguatan sikap spiritual dan sikap sosial, meningkatnya rasa ingin tahu, kreatif, pengetahuan intelektual dan psikomotor

Hakikat ilmu kimia mencakup 3 hal, yaitu kimia sebagai sikap, kimia sebagai produk, dan kimia sebagai proses. Pada dasarnya proses pembelajaran kimia mencakup pembelajaran produk yang terdiri dari fakta, konsep, prinsip, teori dan pembelajaran proses pada kimia untuk memperoleh pengetahuan.

Tuntutan Kurikulum 2013 mengharuskan lulusan SMK memiliki kemampuan di bidang pengetahuan maupun keterampilan. Pembelajaran menggunakan pendekatan ilmiah yang melibatkan siswa dalam penyelidikan dan siswa aktif berinteraksi dengan guru serta siswa lainnya. Oleh karena guru harus kreatif, sehingga konsep kimia yang diajarkan menjadi bermakna.

Berdasarkan hasil penelitian pendahuluan di SMK Farmasi Sekesal Surabaya mata pelajaran Kimia digolongkan sebagai mata pelajaran adaptif yaitu pelajaran yang mendukung kompetensi siswa pada masingmasing bidang keahlian. Akan tetapi dari hasil 
pengamatan ditemukan beberapa fakta yaitu para siswa mempunyai orientasi kalau belajar di SMK hanya untuk belajar mata pelajaran produktif saja, yaitu mata pelajaran yang berhubungan dengan kompetensi kefarmasian saja, sehingga siswa lebih mementingkan mata pelajaran produktif daripada mata pelajaran adaptif.

Berdasarkan nilai hasil belajar siswa SMK Farmasi Sekesal Surabaya kelas X semester ganjil tahun ajaran 2015/2016 mata pelajaran kimia diperoleh nilai prestasi belaja siswa, bahwa ada 3 kelas yang belum mencapai KKM (70) dari 5 kelas secara keseluruhan, yaitu ratarata nilai kelas XC $(67,61)$, kelas XD $(69,86)$ dan XE $(69,63)$. Selain hasil belajar semester ganjil, telah dilaksanakan pretest di kelas XA yang dilakukan terhadap 15 siswa yang terdiri atas 5 siswa dengan kemampuan atas, 5 siswa dengan kemampuan sedang, dan 5 siswa dengan kemampuan bawah diperoleh nilai rata-rata yang diperoleh siswa dalam materi redoks semuanya masih jauh di bawah KKM yaitu 70.Rendahnya nilai siswa tehadap hasil belajar kimia disebabkan rendahnya kemampuan dan minat siswa terhadap pembelajaran kimia yang berdampak pada terhambatnya penguasaan siswa terhadap materi kimia sehingga menyebabkan masih belum mencapai ketuntasan hasil belajar minimal.

Sehubungan dengan rendahnya nilai hasil belajar dan keterampilan argumentasi di lingkungan siswa kelas X SMK Farmasi Sekesal Surabaya terutama pada materi Reaksi Redoks, maka peneliti tertarik untuk mengembangkan perangkat Pembelajaran Kimia dengan model pembelajaran Argument Driven Inquiry pada materi Reaksi Redoks, sehingga diharapkan siswa akan mengalami pergeseran pembelajaran dari menghafal konsep dan teori ke arah berpikir/bernalar sehingga akan menguasai konsep dan teori, serta diharapkan siswa dapat menyampaikan argumentasi ilmiah dengan mudah dalam pembelajaran kimia.

Model pembelajaran Argument Driven Inquiry dapat melatih siswa untuk meningkatkan pemikirannya dengan menekankan pentingnya suatu keterampilan argumentasi dalam meningkatkan dan memvalidasi pengetahuan

Pengembangan Perangkat Pembelajaran Kimia Model Argument Driven Inquiry Untuk Meningkatkan ...... ilmiah (Sampson et al., 2011). Pembelajaran dengan menerapkan model Argument Driven Inquiryakan membantu siswa untuk belajar menghasilkan argumen yang dapat memberikan penjelasan terhadap pertanyaan penelitian sebagai bagian dari proses penelitian (Sampson \& Gleim, 2009). Siswa dituntut untuk merancang dan mengimplementasikan kegiatan penelitiian, mengumpulkan dan menganalisis data, mengkomunikasikan idenya kepada orang lain selama sesi argumentasi, menulis laporan penelitian, dan terlibat dalam kegiatan peer review.

Penelitian dengan menggunakan model pembelajaran Argument Driven Inquiry menunjukan beberapa bukti bahwa kemampuan argumentasi siswa meningkat setealah diterapkan model Argument Driven Inquiryyang dilakukan pada siswa SMP (Ginjar, 2014). Penelitian yang dilakukan oleh Yuli Andriani dan Riandi (2015) tentang Perbandingan Aktifitas Siswa dan Guru Dalam Pembelajaran Argument Driven Inquiry dan Inkuri Terbimbing Pada Pembelajaran IPA Terpadu Kelas VII", yang hasilnya menyatakan bahwa aktifitas siswa dalam pembelajaran Argument Driven Inquiry lebih tinggi jika dibandingkan aktifitas siswa pada pembelajaran inkuiri terbimbing. Penelitian Hasnunidah, dkk. (2015) tentang Peningkatan Pola Wacana Argumentasi Mahasiswa melalui Penggunaan Scaffolding dalam model Argument-Driven Inquiry, yang hasilnya menyatakan bahwa penggunaan scaffolding dalam strategi Argument Driven Inquiry berhasil meningkatkan keterampilan argumentasi mahasiswa. Seluruh hasil penelitian tersebut terbukti baik dan berhasil sebagai solusi dalam melatihkan kemampuan argumentasi siswa.

Peneliti berharap dengan digunakannya pembelajaran dengan model Argument Driven Inquiry dalam pembelajaran kimia di kelas, siswa tidak hanya mempelajari kimia sebagai produk saja akan tetapi juga sebagai proses. Hal ini dikarenakan tujuan dari pembelajaran Argument Driven Inquiry yakni mengubah bentuk pembelajaran dari yang sebelumnya menghafal menjadi pembelajaran bermakna, dan melatihkan keterampilan argumentasi, sehingga dengan demikian dapat meningkatkan 
keterampilan argumentasi dan hasil belajar siswa.

Berdasarkan latar belakang di atas maka peneliti menganggap perlu mengadakan penelitian yang berjudul "Pengembangan Perangkat Pembelajaran dengan Argument Driven Inquiryuntuk Meningkatkan Keterampilan Argumentasi dan Hasil Belajar Siswa.

\section{METODE PENELITIAN}

Penelitian ini merupakan penelitian praeksperimen, yang ditujukan untuk mendeskripsikan pengaruh implementasi pembelajaran dengan Argument Driven Inquiryterhadapketerampilan argumentasi dan hasil belajar siswa pada aspek pengetahuan. Perangkat pembelajaran dikembangkan dengan desain 4D yang telah direduksi menjadi desain 3D yang meliputi tahap pendefinisian (define), tahap perancangan (design), dan tahap pengembangan (develop). Perangkat pembelajaran yang dikembangkan berupa Rencana Pelaksanaan Pembelajaran (RPP), Lembar Kegiatan Siswa (LKS), Buku Ajar Siswa (BAS), tes keterampilan argumentasi, dan Tes Hasil Belajar (THB).

Perangkat yang telah divalidasi kemudian diimplementasikan dengan rancangan penelitian dengan desain the pretest post-test design. Penerapan perangkat dilakukan di SMK farmasi Sekesal Surabaya pada semester 2 tahun ajaran 2016/2017. Penelitian ini ditujukan untuk memperoleh informasi tentang efektivitas perangkat pembelajaran berupa keterlaksanaan, aktivitas siswa, keterampilan argumentasi, hasil belajar siswa dan respon siswa. Instrumen penelitian yang digunakan berupa lembar pengamatan keterlaksanaan pembelajaran, lembar pengamatan aktivitas siswa, lembar tes pemahaman konsep, lembat tes argumentasi, dan lembar respon siswa.

Data yang diperoleh dianalisis secara deskriptif kuantitatif dan kualitatif. Data keterlaksanaan pembelajaran dan respon siswa yang diperoleh dianalisis menggunakan analisis deskriptif kuantitatif, selanjutnya hasil analisis data tersebut dijabarkan menggunakan analisis diskriptif kualitatif untuk memperoleh pernyataan yang menggambarkan kualitas dari angka-angka yang ada. Sementara data aktivitas siswa dianalisis menggunakan analisis deskriptif kuantitatif dengan bentuk diagram. Data hasil belajar siswa dianalisis menggunakan analisis deskriptif kuantitatif, selanjutnya hasil analisis data tersebut dijabarkan menggunakan analisis deskriptif kualitatif untuk memperoleh pernyataan yang menggambarkan kualitas dari angka-angka yang ada. Sugiyono (2011) menyatakan bahwa untuk mengetahui pengaruh pembelajaran terhadap hasil belajar, dilakukan analisis $\mathrm{N}$-gain score dengan rumus sebagai berikut:

$$
\langle g\rangle=\frac{\text { Spost }- \text { Spre }}{\text { Smax }- \text { Spre }}
$$

dengan $(\mathrm{g})=$ nilai gain, Spost $=$ nilai post-test, Spre $=$ nilai pre-test dan Smax $=$ nilai maksimal .

\section{HASIL DAN PEMBAHASAN}

\section{A.Validasi Perangkat Pembelajaran dengan Argument Driven Inquiry}

Berdasarkan hasil validasi oleh validator didapatkan bahwa perangkat pembelajaran dengan Argument Driven Inquiryyang diterapkan oleh peneliti yakni nilai validitas RPP, BAS, LKS, instrumen penilaian hasil belajar aspek pengetahuan dan keterampilan argumentasisecara berturut- turut yaitu 3,67; 3,$64 ; 3,81$; dan 3,51. Hasil penelitian memperoleh skor rata-rata tiga validator pada setiap aspek $\geq 3,0$ dan dinyatakan dalam kriteria sangat valid dan bisa digunakan oleh siswa dan guru dalam pembelajaran kimia

\section{B.Keterlaksanaan Pembelajaran dengan model Argument Driven Inquiry}

Berdasarkan pengamatan yang dilakukan oleh observer menunjukkan bahwa skor rata-rata keterlaksanaan pembelajaran sebesar 3,79 dan reliabilitas rata-rata sebesar 94,11\%.. Hasil tersebut menunjukkan bahwa pelaksanaan kegiatan pembelajaran dengan model Argument Driven Inquiryterlaksana dengan baik. Selain itu, seluruh langkah-langkah 
pembelajaran pada RPP dilaksanakan oleh guru. Hasil penelitian menunjukkan bahwa guru dapat melaksanakan dan mengelola pembelajaran dengan baik sesuai dengan standar kompetensi pedagogik. Keterlaksanaan pembelajaran yang baik akan berdampak pada pencapaian tujuan pembelajaran, sehingga hasil belajar siswa dapat ditingkatkan.

\section{C.Respon Siswa}

Sebagian besar siswa menyatakan tertarik dan mudah memahami bahan ajar, suasana belajar, cara mengajar guru, dan tahaptahap yang diarahkan dalam pembelajaran dengan Argument Driven Inquiry. Hal tersebut didukung dengan keterlaksanaan pembelajaran yang dilakukan guru mendapat penilaian sangat baik, validitas perangkat pembelajaran yang dikembangkan oleh peneliti juga mendapatkan kategori sangat valid. Sebagian besar siswa menyatakan penjelasan dan cara guru menerapkan pembelajaran dengan model Argument Driven Inquirybaik, hal ini dikarenakan guru menggunakan bahasa yang mudah dipahami dan komunikatif. Sebagian besar siswa menyatakan berminat mengikuti kembali pembelajaran dengan model Argument Driven Inquirypada pertemuan berikutnya. Hal ini dikarenakan pembelajaran yang dilakukan melibatkan siswa secara aktif yaitu kegiatan praktikum dan kegiatan pembelajaran melibatkan hal-hal yang dekat dengan kehidupan sehari-hari yang dialami siswa. Siswa juga tertarik untuk mengikuti pembelajaran dengan model Argument Driven Inquirysehingga meningkatkan motivasi mereka untuk belajar, sehingga dapat meningkatkan hasil belajarnya.

\section{D.Aktivitas Siswa}

Sebagian besar siswa pada saat pembelajaran melakukan aktivitas positif dalam pembelajaran seperti mengidentifikasi masalah penelitian, memperoleh data, membangun argumen tentatif, mengadakan sesi argumentasi, menyusun laporan penelitian secara tertulis, mengadakan peer review hasil laporan penelitian, mengadakan revisi laporan berdasarkan hasil peer review, dan mengadakandiskusi eksplisit dan reflektif. Hal tersebut menunjukkan bahwa pembelajaran dengan model Argument Driven Inquirydapat meningkatkan keterlibatan siswa secara aktif dalam pembelajaran. Tahapan-tahapan pada pembelajaran dengan model Argument Driven Inquiry memungkinkan siswa untuk terlibat secara aktif dalam pembelajaran.

\section{E.Efektifitas Perangkat Pembelajaran dengan model Argument Driven Inquiry}

\section{Keterampilan Argumentasi}

Persentase ketuntasan hasil belajar saat pretest sebesar $0 \%$, artinya semua siswa pada saat dilakukan pretest di awal pembelajaran tidak mencapai nilai minimal 80. Setelah siswa diberikan model pembelajaran argument driven inquiry dan dilakukan posttest, persentase ketuntasannya sebesar $96,67 \%$, artinya sebagian besar siswa telah mencapai ketuntasan keterampilan argumentasi.

Peningkatan keterampilan argumentasi dianalisis menggunakan $n$-gain. Dari nilai gain menunjukkan perbedaan hasil belajar siswa sebelum dan sesudah pembelajaran. Ada 28 siswa memperoleh skor $n$-gain dalam kategori tinggi dan 2 siswa dalam katagori sedang. Hasil ini menunjukkan bahwa model pembelajaranargument driven inquiry efektif dalam meningkatkan keterampilan argumentasi siswa.

\section{Hasil Belajar Siswa Aspek Pengetahuan}

Mengacu pada Panduan Penilaian untuk SMK dari Kemendikbud, nilai ketuntasan hasil belajar meliputi aspek pengetahuan, sikap, dan keterampilan. Kriteria Ketuntasan Minimal (KKM) untuk aspek pengetahuan yang ditetapkan adalah 80 dengan predikat $\mathrm{C}$ (Cukup). Pada saat dilakukan pretest didapatkan bahwa tidak ada siswa yang mencapai nilai 80 akan tetapi setelah dilakukan pembelajaran dengan model Argument Driven Inquiryterjadi peningkatan hasil belajar siswa pada aspek pengetahuan. Persentase ketuntasan siswa adalah $100 \%$, artinya seluruh siswa memiliki nilai $\geq 80$. Pembelajaran dengan model Argument Driven Inquiryefektif untuk meningkatkan keterampilan argumentasi dan hasil belajar siswa, dikarenakan tahapan-tahapan pembelajaran yang dialami siswa melatihkan argumentasi siswa. Pembelajaran dengan model Argument Driven Inquiry memiliki delapan fase, yaitu: identifikasi masalah penelitian, perolehan data, membangun 
argumen tentatif, sesi argumentasi, menyusun laporan penelitian secara tertulis, peer review hasil laporan penelitian, revisi laporan berdasarkan hasil peer review, dan Diskusi eksplisit dan reflektif(Sampson \& Gleim, 2009).

Semua tahapan model pembelajaran Argument-Driven Inquiry efektif memberikan sarana untuk melatihkan argumentasi ilmiah siswa. Apabila argumentasi ilmiah siswa meningkat, maka secara otomatis konsep pokok yang mendasar dalam ilmu sains dapat dipahami dengan mudah. Selain itu model pembelajaranArgument Driven Inquiryefektif untuk meningkatkan keterampilan argumentasi dan hasil belajar siswa. Hal ini didasarkan atas uraian yang telah dijelaskan $\mathrm{di}$ atas. Keterlaksanaan pembelajaran pada tahap pendahuluan dari tiga kali pertemuan mendapatkan skor rata-rata 3,91 dengan predikat sangat baik, artinya guru dapat melaksanakan tahapan pertama dan persiapan dengan baik. Persentase aktivitas siswa saat memperhatikan fenomena yang disajikan guru sebesar 6,9\%, artinya sebagian besar siswa tertarik dan fokus terhadap fenomena yang guru sajikan pada tahapan tersebut. Keterlaksanaan pembelajaran pada tahap inti dari tiga kali pertemuan mendapatkan skor rata-rata 3,67 dengan predikat baik. Keterlaksanaan pembelajaran pada tahap penutup mendapatkan skor rata-rata 3,67 dengan predikat baik, artinya guru melakukan tahapandiskusi reflektif eksplisit dengan baik. Penerapan model pembelajaranargument driven inquirymembuat suasana kelas menjadi kondusif untuk siswa belajar. Hal ini dapat dilihat dari hasil keterlaksanaan pembelajaran aspek suasana kelas sebesar 3,8 dengan predikat baik.

2.Peningkatan Hasil Belajar Siswa

Salah satu indikator yang dapat dijadikan acuan apakah perangkat pembelajaran yang efektif adalah dengan melihat peningkatan hasil belajar siswa, yang dalam hal ini adalah peningkatan penguasaan konsepnya. Siswa diberikan tes sebelum dan sesudah mengikuti pembelajaran dengan model argument driven inquiry. Hal ini untuk mengetahui seberapa efektif perangkat pembelajaran yang dikembangkan untuk meningkatkan penguasaan konsep siswa. Hasil belajar siswa meningkat secara signifikan yang dinyatakan dengan skor Normalized Gain (n-gain). Jumlah siswa yang memiliki skor n-gain $<0,70$ sebanyak 30 siswa dengan kategori tinggi.

Model pembelajaranargument driven inquiry efektif untuk meningkatkan keterampilan argumentasi dan hasil belajar siswa. Hasil penelitian yang menyatakan bahwa perangkat pembelajaran kimia model argument driven inquiryvalid, praktis dan efektif dalam meningkatkan hasil belajar siswa mendukung beberapa penelitian sebelumnya yang meneliti tentang model pembelajaran argument drivent inquiry. Ginanjar (2014), dari hasil penelitianya menyatakan bahwa terdapat peningkatan yang signifikan keterampilan Argumentasi Ilmiah Siswa setelah menggunakan model pembelajaran Argument Driven Inquiry.Andriani dan Riandi (2015), dari hasil penelitianya menyatakan bahwa aktivitas siswa dalam pembelajaran Argument Driven Inquiry lebih tinggi jika dibandingkan aktivitas siswa pada pembelajaran inkuiri terbimbing.Hasnunidah, Susilo, Irawati, Sutomo (2015), dari hasil penelitianya menyatakan bahwa penggunaan scaffolding dalam strategi Argument Driven Inquiry berhasil meningkatkan keterampilan argumentasi mahasiswa.

\section{IV .PENUTUP}

\section{A. Simpulan}

Berdasarkan hasil dan pembahasan dapat disimpulkan bahwa pengembangan perangkat pembelajaran dengan menggunakan model pembelajaran Argument Driven Inquirymemiliki kategori valid, praktis, dan efektif sehingga layak digunakan untuk meningkatkan keterampilan argumentasi dan hasil belajar siswa pada materi reaksi redoks.

\section{B. Saran}

Hendaknya mencoba untuk mengembangkan perangkat model pembelajaran Argumen Driven Inquiryuntuk meningkatkan keterampilan argumentasi dan hasil belajar siswa dari materi pembelajaran kimia yang lain.

\section{DAFTAR PUSTAKA}


Berg, C. A. R., Bergendahl, V. C. B., \& Lundberg, B. K. S. (2003). Benefiting from an open-ended experiment? A comparison of attitudes to, and outcomes of, an expository versus an open-inquiry version of the same experiment. International Journal of Science Education. 25(3), 112121.

Chang and Chiu, (2008). Lactos's Science Research : Programmes as a framework for analysing Infromal Argumentation about Sosio-scientific Issues. International Journal of Science Education, Vo;. 30 No. 17, pp. 1753-1773.

Devi, S dan Khairuddin, 2009. Pengembangan Perangkat Pembelajaran untuk Guru SMP. Jakarta: Pusat Pengembangan dan Pemberdayaan Pendidik dan Tenaga Kependidikan Ilmu Pengetahuan Alam (PPPPTK IPA) untuk Program Bermutu.
Nur, M. 2008. Pengajaran Berpusat kepada Siswa dan Pendekatan Konstruktivis dalam Pengajaran. Surabaya: Pusat Sains dan Matematika Sekolah Unesa.

Sampson, V. \& Gleim, L. (2009). ArgumentDriven Inquiry to promote the understanding of important concepts \& practices in biology. The American Biology Teacher, Vol. 71(8): 465-472.

Suyono dan Hariyanto. 2011. Belajar dan Pembelajaran. Bandung: Remaja Rosda Karya.

Tien Wu, Y \& Chung Tsai, C. 2005. Journal of Biological Education, 39(3).

Walker, J. P. dan Sampson, V. (2013), Learning to argue and arguing to learn:argument driven inquiry as way to help undergraduate chemistry studentslearn to how to contruct argument and engage in argumentationduring a laboratory course. Journal of Research in Science teaching. 